\title{
The Breakdown Voltage Characteristics of Bamboo Insulation under Composite Layer Based
}

\author{
Lukmanul Hakim $^{1}$, T. Haryono ${ }^{2}$, Suharyanto ${ }^{3}$
}

\begin{abstract}
Today, insulation system involves more than one insulation material, whether serial, parallel, or both. In insulation system, the simplest form is composite which consists of two layers of the same material. The benefit of using layered insulation is that the dielectric strength is higher than one layer with the same thickness. There are two methods to test bamboo isolator, i.e., tests of the breakdown voltage of bamboo wall and bamboo fiber. The tests used two methods of composite layers (acrylic and resin) and without composite layer (normal condition). The tests were intended to observe the breakdown voltage on each incidence in each test sample and discover the dielectric strength. The test result showed that the breakdown voltage of bamboo wall was bigger than bamboo fiber with or without composite layer. The highest dielectric strengths of acrylic layer in petung bamboo wall were $2.07 \mathrm{kV} / \mathrm{mm}$ and acrylic layer in bamboo fiber was $0.95 \mathrm{kV} / \mathrm{mm}$ in layered method. Meanwhile, in ampel bamboo wall it was $1.35 \mathrm{kV} / \mathrm{mm}$ and petung bamboo fiber it was $0.43 \mathrm{kV} / \mathrm{mm}$ in normal condition (without layer).
\end{abstract}

Keyword-insulation, bamboo, composite coating, breakdown voltage, dielectric strength.

\section{INTRODUCTION}

The primary function of isolator is isolating conductor to prevent leakage current, isolating conductor for not having a direct contact to another conductor and contact to tower sections. Even though there is high field gradient, there is no electric jump, i.e., flashover or sparkover [1]. The voltage applied on insulation material is a pull/stress which must be resisted by a power in the insulation itself so that the insulation property does not fail. The current which can flow through solid insulation depends on the physical and chemical structures of the insulation [2]. Currently, ceramic, porcelain, and glass isolators are massively used, showing energy wastage, especially in the production process. Most isolators are used outdoors, e.g. power plant, substation, high voltage transmission, extra high transmission, and distribution [3], [4]. Wood and bamboo are building materials which have been used for a long time. One of solid insulation materials which is dielectric material is wood. However, the parallel tensile strength of fiber in bamboo internode is bigger than wood, even plain reinforcing steel [5]. It's because the modulus of bending elasticity of bamboo is bigger the deeper into the skin [6]. During its growth, certain bamboo can grow $5 \mathrm{~cm}$ per

\footnotetext{
${ }^{1}$ Student, Department of Electrical Engineering and Information Technology, Faculty of Engineering, Universitas Gadjah Mada, Yogyakarta 55581 INDONESIA (e-mail: ancortaqim@gmail.com)

${ }^{2,3}$ Lecturer, Department of Electrical Engineering and Information Technology, Faculty of Engineering, Universitas Gadjah Mada, Yogyakarta 55581 INDONESIA
}

hour vertically, or $120 \mathrm{~cm}$ per day. Unlike forest trees which are only ready to be cut with good quality at the age of 40-50 years, good quality bamboo can be obtained at the age of 3-5 years. Bamboo is one of a kind on solid insulating material which is included in the dielectric material, nevertheless the research of bamboo as an insulating material in electrical power system were not mostly done more research specifically. Therefore, due to insulating standard, a research of high voltage characteristic was conducted to know the breakdown voltage and the dielectric strength of bamboo as an insulator material.

Several high voltage tests were applied to bamboo types. The bamboo types were ampel bamboo (Bamboosa vulgaris), apus bamboo (Gigantochloa apus Kurz), legi bamboo (Gigantochloa atter), petung bamboo (Dendrocalamus asper), and wulung bamboo (Gigantochloa Atroviolacea). To meet insulation standard, there should be research and test of high voltage to determine the characteristics of breakdown voltage of the bamboos as isolator materials. There are two methods to test bamboo isolator, i.e., tests of the breakdown voltage of bamboo wall and bamboo fiber. The tests used two methods of composite layers (acrylic and resin) and without composite layer (normal condition). Finishing work on bamboo was aimed to put acrylic, melamine, resin or a substance on bamboo surface to get certain benefits. The benefit of layering or smearing is increasing dielectric strength and breakdown voltage of bamboo isolator. Moreover, layering or smearing preserve materials by protecting them.

\section{ISOLATOR, BAMBOO, AND EPOXY RESIN}

The isolator acts as a conductor support and simultaneously separates the conductor from the zero-voltage conductor. In addition, the insulator is also used in air distribution network, which serves as a hanger or conductor support [6]. Isolator is a material that serves as a separator of two or more electrical conductors in a voltage condition so that no leakage current [7]. At high voltage, the dielectric ability of insulating material is vital to determine the quality of insulator which will support the performance of electric power system. Dense dielectric materials are used in almost all circuits and electrical appliances. Good dielectric materials must have low losses, high mechanical strength, free from gas and dust formation, and resistant to temperature and chemical changes. Solid insulation has a high penetrating force strength compared to both liquid and gas insulation [8].

Currently bamboo is becoming more popular as a nonwood material in the field of construction. Since bamboo has beneficial properties such as having a relatively short growth time (3-5 years), bamboo has a high strength to weight ratio, and the cost is relatively low [9]. Bamboo stems consist of 
segments (nodia) and internodia. The stem cells have an axial orientation and do not have radial cells. The bamboo walls are composed of $50 \%$ parenchymal tissue, $40 \%$ fiber, $10 \%$ vessels and vascular bundles [10]. Structural strength and hardness of bamboo stems are caused by the fibers and lignin tracheid that are possessed, comprising cellulose. In addition, bamboo stems also contain a lot of silica (5\%). Although the bamboo stem is not a tree, it can be very hard because of its silica and lignin content. Bamboo is a hygroscopic material, meaning that bamboo has an affinity for water in both vapor and liquid form. The ability of bamboo to absorb water depends on the temperature and humidity of the atmosphere where the bamboo is located. Bamboo which is placed in an open atmosphere will reach a certain water content that has been balanced with the surrounding air. This moisture content is called air dry air content [11].

Epoxy resin liquid is a liquid that has a low viscosity properties so it is easily mixed (enter thermoset stage). Other resin liquids such as phenolics, polyesters, acrylics are made in the same process, but the epoxy resin has a combination of low viscosity, shaping, low shrinkage, high adhesiveness, high mechanical properties, high electrical insulation, and good chemical resistance [12], [13]. Acrylic is a glass-like plastic, but has properties that make it superior to glass in many ways one of which is the flexibility of the acrylic itself. It takes temperatures from $250^{\circ} \mathrm{F}$ to $300^{\circ} \mathrm{F}$ (from $121^{\circ} \mathrm{C}$ to $149^{\circ} \mathrm{C}$ ) to bend and form acrylic plastic. Acrylic plastic refers to a group of synthetic plastic materials, derived from acrylic acids [14].

\section{Methodology}

The research on insulation material test used five types of bamboo, i.e. ampel bamboo, ampus bamboo, legi bamboo, petung bamboo, and wulung bamboo in normal condition and composite layers or smears (acrylic and resin) applied as isolator material. The tests were done to obtain the breakdown voltage of bamboo wall (not in the same direction as bamboo fiber) and in the same direction as bamboo fiber. Breakdown voltage test on bamboo wall with layers was performed on the inner and outer parts of bamboo. In breakdown voltage test in the same direction as bamboo fiber, layering was performed on each end of bamboo. Fig. 1 shows examples of bamboo walls and bamboo fiber.

Bamboo samples were designed having certain dimension, thickness, and maturity in each bamboo sample to get more precise breakdown voltage test.

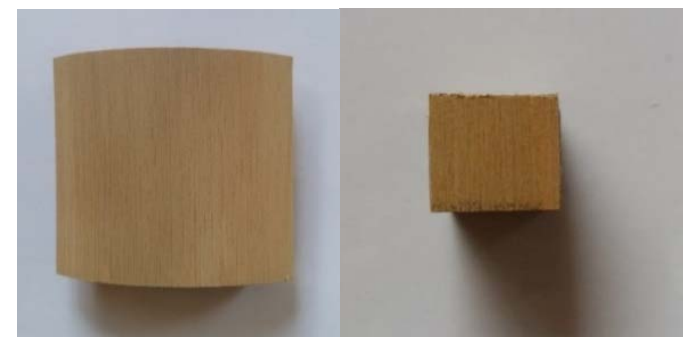

(a)

(b)

Fig. 1(a) Examples of bamboo walls, (b) Bamboo fiber sample.
On bamboo wall, test was performed by clamping the outer and inner bamboo wall by rod electrodes, as shown in Fig. 2. This was performed on five samples of five bamboo types in normal condition (without layer) and with composite layers (acrylic and resin). Similarly, bamboo fiber was tested by clamping each end using rod electrode with the same treatments, i.e. test in normal condition (without layer) and with composite layers (acrylic and resin) on the same number of samples, i.e. five sample of five bamboo types.

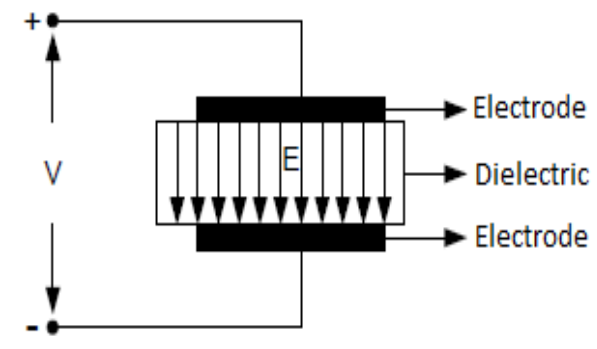

Fig. 2 Electric exposure in dielectric.

Fig. 3 shows the circuit of high voltage test. High voltage was generated by step-up transformer whose primary winding received $220 \mathrm{~V} / 50 \mathrm{~Hz}$ input voltage from utility. Secondary voltage of the transformer produced $50 \mathrm{kV}$ output in its secondary winding. The output voltage was connected to electrodes which served as anode and cathode. SVR (Sliding Voltage Regulator) was rolled to regulate the output voltage.

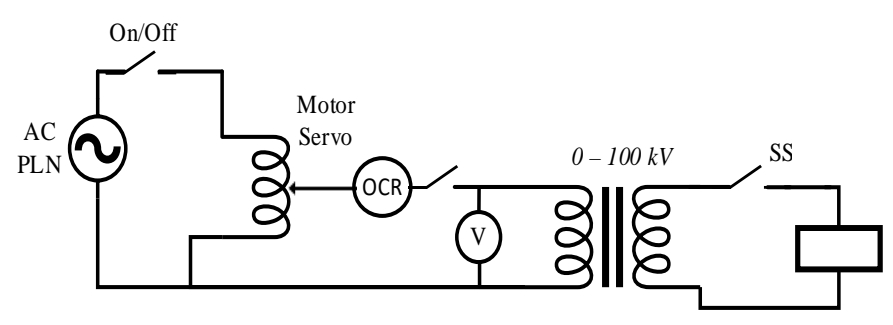

Trafo Step Up

Fig. 3 Circuit of bamboo breakdown voltage test.

This test aimed to determine the characteristics of breakdown voltage of insulators made from ampel, apus, legi, petung, and wulung bamboo. This test used high-voltage AC with frequency of $50 \mathrm{~Hz}$ according to IEC 60-1 standard. This test used two rod electrodes with cross-sectional area of 1.25 $\mathrm{cm}^{2}$ each. Both electrodes were mounted on a tamperable test apparatus according to the thickness of the sample to be tested. The first electrode was connected to a high-voltage AC controlled by the measuring equipment, and the second one was connected to a grounding channel. The sample of the insulator material to be tested was installed between the two electrodes and clamped by both electrodes. Measurements were done by slowly raising the voltage until arcs occuring and jumping between the two electrodes and penetrate the test material. This event is the occurrence of isolation failure caused by dielectric strength in the material only at the voltage value when arc occur. 


\section{Results}

Breakdown voltage was tested on $5 \mathrm{~cm}$ x $5 \mathrm{~cm}$ ampel bamboo with $1.3 \mathrm{~cm}$ thickness. The temperature was $29^{\circ} \mathrm{C}$, air pressure was $74 \mathrm{mmHg}$, and humidity was $67 \%$. The test was performed five times with test patterns on bamboo wall and bamboo. The results are shown in Table I and Table II. The graphs of average breakdown voltage and dielectric strength are shown in Fig. 4 and Fig. 5.

TABLE I

TESTING OF BREAKDOWN VOLTAGE ON BAMBOO WALL WITH NORMAL CONDITION

\begin{tabular}{|c|c|c|c|c|c|c|}
\hline \multirow{3}{*}{$\begin{array}{r}\text { Type of } \\
\text { bamboo }\end{array}$} & & & nul & & & \multirow{3}{*}{ Status } \\
\hline & 1 & 2 & 3 & 4 & 5 & \\
\hline & \multicolumn{5}{|c|}{ Breakdown voltage $(\mathrm{kV})$} & \\
\hline Ampel & 20 & 17 & 19 & 16 & 16 & Breakdown \\
\hline Apus & 14 & 14 & 14 & 14 & 14 & Breakdown \\
\hline Legi & 14 & 12 & 11 & 12 & 12 & Breakdown \\
\hline Petung & 16 & 14 & 14 & 14 & 12 & Breakdown \\
\hline Wulung & 16 & 17 & 15 & 16 & 18 & Breakdown \\
\hline
\end{tabular}

TABLE II

TESTING OF BREAKDOWN VOLTAGE ON BAMBOO FIBER WITH NORMAL CONDITION

\begin{tabular}{|c|c|c|c|c|c|c|}
\hline \multirow{2}{*}{$\begin{array}{c}\text { Type of } \\
\text { bamboo }\end{array}$} & \multicolumn{5}{|c|}{ Test number } & \multirow{2}{*}{ Status } \\
\cline { 2 - 6 } & $\mathbf{1}$ & $\mathbf{2}$ & $\mathbf{3}$ & $\mathbf{4}$ & $\mathbf{5}$ & \multirow{2}{*}{ Breakdown voltage (kV) } \\
\hline Ampel & 5 & 4 & 4 & 4 & $\mathbf{4}$ & Breakdown \\
\hline Apus & 3 & 3 & 3 & 3.5 & 3 & Breakdown \\
\hline Legi & 3 & 2 & 2 & 3 & 3 & Breakdown \\
\hline Petung & 6 & 5 & 6 & 6 & 5 & Breakdown \\
\hline Wulung & 4 & 3.5 & 3 & 3.5 & 3 & Breakdown \\
\hline
\end{tabular}

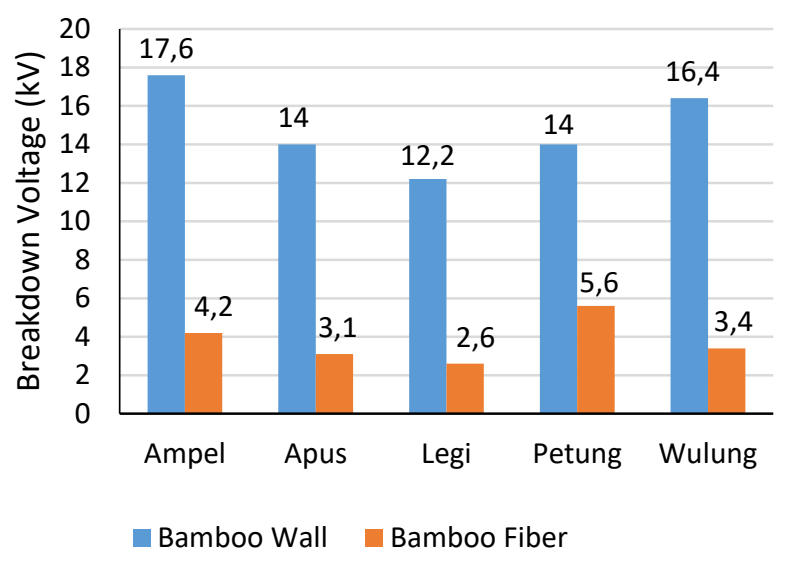

Fig. 4 Average breakdown voltage of bamboo wall and bamboo fiber.

Different environments around isolators across the world make voltage failure calculation requiring a correction factor to obtain standard value of voltage failure. Therefore, a correction was made using temperature, air pressure, and humidity when voltage failure was obtained.

Ampel bamboo (Bamboosa vulgaris) has the highest average breakdown voltage on bamboo wall, because the nature of its surface is coated with white wax when it is still young and gradually becomes shiny after being old. This makes the natural coating of the ampel bamboo wall is smoother, denser, and waterproof. Meanwhile, testing of bamboo fiber, petung bamboo (Dendrocalamus asper) has the highest average breakdown voltage. This is because petung has a high percentage of fibers and fiber bonds are relatively large [7]. The average rod fiber dimension has a length of 3.78 $\mathrm{mm}$, diameter $19 \mu \mathrm{m}$, width of lumen $7 \mu \mathrm{m}$, and wall thickness $6 \mu \mathrm{m}$ [8].

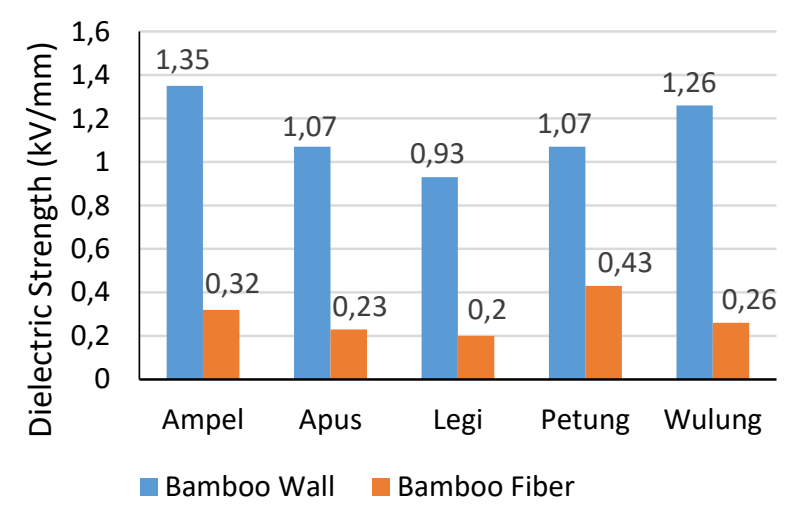

Fig. 5 Average dielectric strength of bamboo wall and bamboo fiber.

TABLE III

TESTING OF BREAKDOWN VOLTAGE ON BAMBOO WALL WITH ACRYLIC LAYER TREATMENT

\begin{tabular}{|c|c|c|c|c|c|c|}
\hline \multirow{3}{*}{$\begin{array}{l}\text { Type of } \\
\text { bamboo }\end{array}$} & & $\mathrm{Te}$ & nun & er & & \multirow{3}{*}{ Status } \\
\hline & 1 & 2 & 3 & 4 & 5 & \\
\hline & \multicolumn{5}{|c|}{ Breakdown voltage $(\mathrm{kV})$} & \\
\hline Ampel & 26 & 26 & 25 & 25 & 23 & Flashover \\
\hline Apus & 24 & 24 & 26 & 24 & 25 & Flashover \\
\hline Legi & 21 & 24 & 24 & 24 & 23 & Flashover \\
\hline Petung & 28 & 25 & 29 & 27 & 26 & Flashover \\
\hline Wulung & 26 & 26 & 26 & 24 & 26 & Flashover \\
\hline
\end{tabular}

TABLE IV

TESTING OF BREAKDOWN VOLTAGE ON BAMBOO FiBER WITH ACRYLIC LAYER TREATMENT

\begin{tabular}{|c|c|c|c|c|c|c|}
\hline \multirow{2}{*}{$\begin{array}{c}\text { Type of } \\
\text { bamboo }\end{array}$} & \multicolumn{7}{|c|}{ Test number } & \multirow{2}{*}{ Status } \\
\cline { 2 - 6 } & $\mathbf{1}$ & $\mathbf{2}$ & $\mathbf{3}$ & $\mathbf{4}$ & $\mathbf{5}$ & \multirow{2}{*}{ Breakdown voltage (kV) } \\
\hline Ampel & 8 & 9 & 6 & 7 & 7 & Breakdown \\
\hline Apus & 10 & 10 & 9 & 9 & 9 & Breakdown \\
\hline Legi & 8 & 7 & 5 & 6 & 7 & Breakdown \\
\hline Petung & 14 & 14 & 10 & 12 & 12 & Breakdown \\
\hline Wulung & 8 & 9 & 6 & 7 & 8 & Breakdown \\
\hline
\end{tabular}

The results of voltage test on acrylic layer treatment on bamboo and fiber are shown in Table III and Table IV. Graphs of average breakdown voltage and dielectric strength are presented in Fig. 6 and Fig. 7.

The voltage on acrylic layer did not penetrate test materials (breakdown) but experienced failure through flash due to very high density of acrylic layer, producing very smooth surface of acrylic layer, so it was very vulnerable to flashover. Petung has the highest average breakdown voltage on bamboo wall and bamboo fiber. 


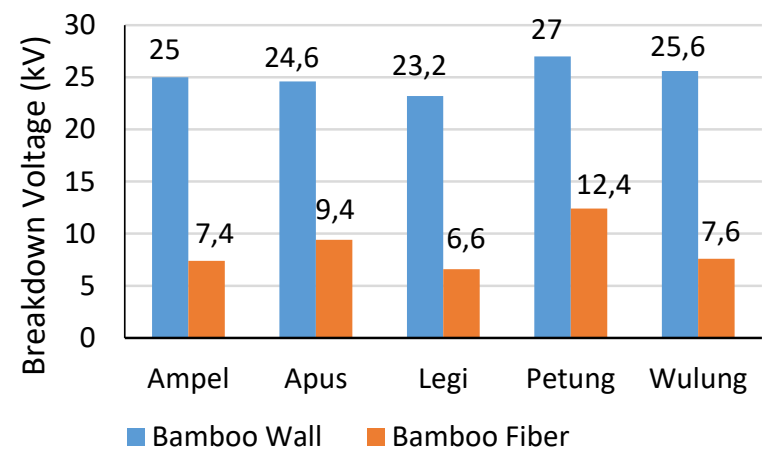

Fig. 6 Average breakdown voltage of bamboo wall and bamboo fiber.

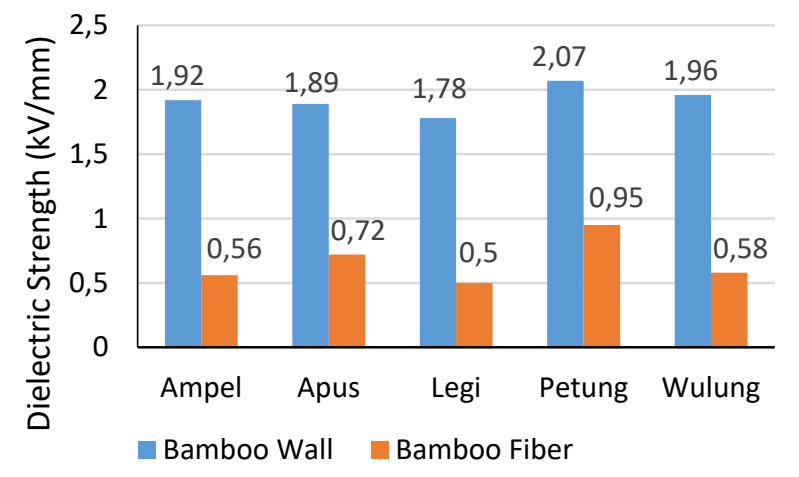

Fig. 7 Average dielectric strength of bamboo wall and bamboo fiber.

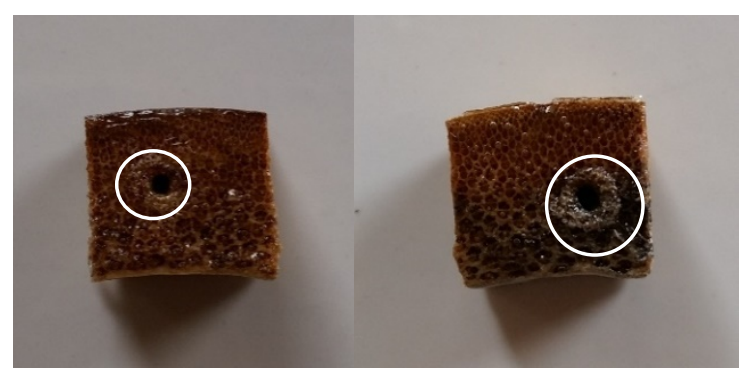

Fig. 8 Puncture breakdown of bamboo fiber.

TABLE V

TESTING OF BREAKdOWN VOLTAGE ON BAMBOO WALL WITH RESIN LAYER TREATMENT

\begin{tabular}{|c|c|c|c|c|c|c|}
\hline \multirow{3}{*}{$\begin{array}{l}\text { Type of } \\
\text { bamboo }\end{array}$} & & & t nu & ber & & \multirow{3}{*}{ Status } \\
\hline & 1 & 2 & 3 & 4 & 5 & \\
\hline & \multicolumn{5}{|c|}{ Breakdown voltage (kV) } & \\
\hline Ampel & 25 & 22 & 26 & 26 & 24 & Breakdown \\
\hline Apus & 22 & 22 & 24 & 24 & 23 & Breakdown \\
\hline Legi & 19 & 18 & 18 & 22 & 22 & Breakdown \\
\hline Petung & 28 & 27 & 24 & 24 & 24 & Breakdown \\
\hline Wulung & 23 & 24 & 20 & 20 & 24 & Breakdown \\
\hline
\end{tabular}

In contrast to testing on bamboo walls that experienced flashover, testing of fibers with acrylic coating experienced a breakdown voltage. Fig. 8 shows a form of puncture breakdown in which the insulator can not recover as before and some of the insulators have mechanical damage resulting in non-reusable.
TABLE VI

TESTING OF BREAKDOWN VOLTAGE ON BAMBOO FIBER WITH RESIN LAYER TREATMENT.

\begin{tabular}{|c|c|c|c|c|c|c|}
\hline \multirow{3}{*}{$\begin{array}{l}\text { Type of } \\
\text { bamboo }\end{array}$} & & Te & nu & & & \multirow{3}{*}{ Status } \\
\hline & 1 & 2 & 3 & 4 & 5 & \\
\hline & \multicolumn{5}{|c|}{ Breakdown voltage (kV) } & \\
\hline Ampel & 7 & 8. & 7 & 7 & 7 & Breakdown \\
\hline Apus & 7 & 7. & 9 & 7 & 6 & Breakdown \\
\hline Legi & 7 & 7 & 6 & 6 & 6 & Breakdown \\
\hline Petung & 9 & 7. & 7 & 7 & 8 & Breakdown \\
\hline Wulung & 7 & 8 & 7 & 7 & 7. & Breakdown \\
\hline
\end{tabular}

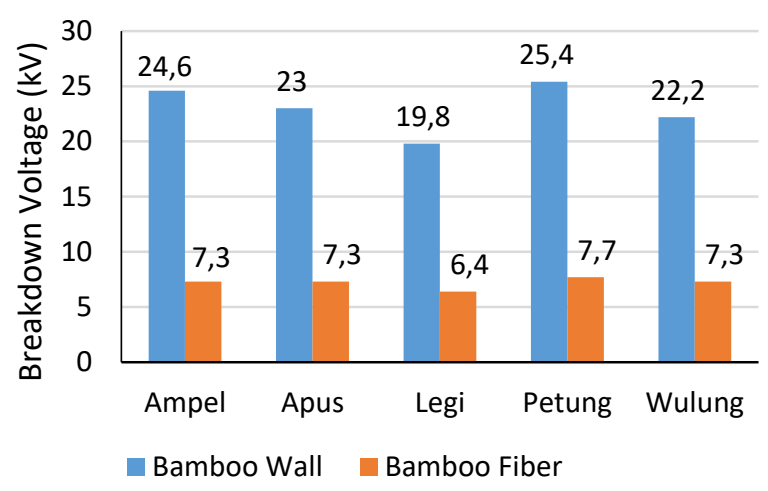

Fig. 9 Average breakdown voltage of bamboo wall and bamboo fiber.

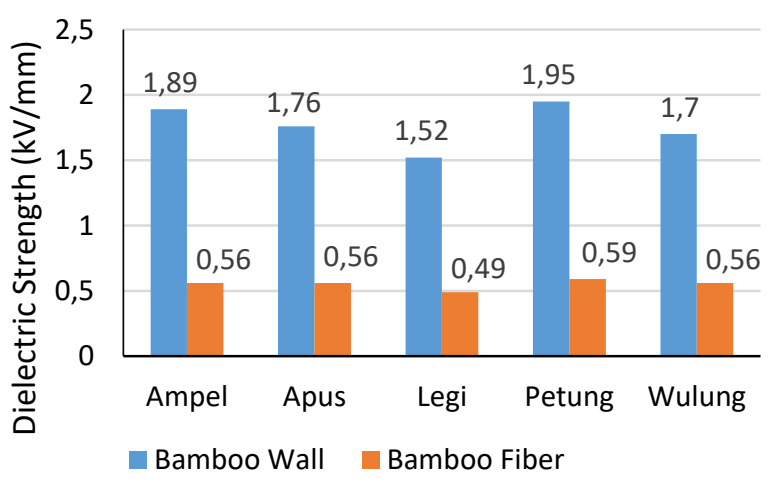

Fig. 10 Average dielectric strength of bamboo wall and bamboo fiber.

The results of voltage test on resin layer treatment on bamboo and fiber are shown in Table V and Table VI. Graphs of average breakdown voltage and dielectric strength are presented in Fig. 9 and Fig. 10.

Petung bamboo (Dendrocalamus asper) produced the highest average breakdown voltage on bamboo wall and bamboo fiber resin layer treatment. This was because petung has a high percentage of fibers and fiber bonds were relatively large [7]. The average rod fiber dimension has a length of 3.78 $\mathrm{mm}$, diameter $19 \mu \mathrm{m}$, width of lumen $7 \mu \mathrm{m}$, and wall thickness $6 \mu \mathrm{m}$ [8].

\section{CONCLUSION}

Based on the breakdown voltage test, the biggest dielectric strengths of bamboo walls with and without layer in acrylic layer on petung bamboo was $2.07 \mathrm{kV} / \mathrm{mm}$, resin layer on 
petung bamboo was $1.95 \mathrm{kV} / \mathrm{mm}$, and without layer on ampel bamboo was $1.32 \mathrm{kV} / \mathrm{mm}$. In breakdown voltage test on bamboo fiber, acrylic layer the biggest average dielectric strength in petung bamboo, which was $0.95 \mathrm{kV} / \mathrm{mm}$, resin layer on petung bamboo was $0.59 \mathrm{kV} / \mathrm{mm}$, and without layer on petung bamboo was $0.43 \mathrm{kV} / \mathrm{mm}$. The voltage on acrylic layer did not penetrate test materials (breakdown) but experienced failure through flash due to very high density of acrylic layer, producing very smooth surface of acrylic layer, so it was very vulnerable to flashover.

\section{REFERENCES}

[1] Arismunandar, A., Teknik Tegangan Tinggi, Suplemen Pertama. Jakarta, Indonesia: Ghalia Indonesia, 1982.

[2] D. Kind, An Introduction to High Voltage Experimental Techniques, New Delhi, India: Wiley Eastern Limited, 1978.

[3] Hackam, R, “Outdoor High Voltage Polymeric Insulators,” Proceedings of 1998 International Symposium on Electrical Insulating Material, 1998, paper IM-1, pp. 1-16.

[4] Berahim, H, "Pengaruh Silane sebagai Bahan Pengisi Material Isolasi Polimer Resin Epoksi di Daerah Tropis,” Media Tek., Vol. 28, No. 3, pp. 48-53, 2006.

[5] Morisco, “Teknologi Bambu,” Universitas Gadjah Mada, Technical Report, 2005.
[6] J. Ma, W. Chen, L. Zhao, and D. Zhao, "Elastic Buckling of Bionic Cylindrical Shells Based on Bamboo,” Journal of Bionic Eng., Vol. 5, No. 3, pp. 231-238, 2008.

[7] A. Kadir, Transmisi Tenaga Listrik, Edisi Revisi. Jakarta: Universitas Indonesia, 1998.

[8] B. L. Tobing, Dasar Teknik Tegangan Tinggi. Jakarta: PT. Gramedia Pustaka Utama, 2003.

[9] M. Anas Wirawan and A. Purnomo, "Sifat Isolasi dan Proses Kegagalan Bahan Isolasi Padat,” Universitas Muhammadiyah Surakarta, Tech. Report, pp. 1-11, 2010.

[10] J. F. D. Correal and C. J. Arbeldez, "Influence of Age and Height Position on Colombia Guadua Angustifolia Bamboo Mechanical Properties,” Maderas. Ciencia y Tecnología, Vol. 12, No. 2, pp. 105113, 2010.

[11] M. Riyadi and Amalia, "Teknologi Bahan", Politeknik Negeri Jakarta, Lecture Note, 2005.

[12] F. R. Wijaya, "Pengaruh Pengawetan dengan Metode Perendaman dalam Larutan Prusi Terhadap Karakteristik Bambu Ampel (Bambusa vulgaris Schrad),” Thesis, Universitas Gadjah Mada, Indonesia, 2003.

[13] Prasojo, A. Winarko, S. Abdul, and Yuningtyastuti, “Analisis Partial Discharge pada Material Polimer Resin Epoksi dengan Menggunakan Elektroda Jarum Bidang.” Thesis, Universitas Diponegoro, Indoensia, 2009.

[14] Lee, Henry, and Kris Neville, Epoxy Resins Their Applications and Technology. London, UK: McGraw-Hill Book Company, Inc., 1957. 